\title{
Preconception of Pharmacy Students for the Inclusion of Entrepreneurship Curriculum in the PharmD Program
}

\author{
Ahmed Abdelrahman Albarraq ${ }^{1}$, Hafiz Antar Makeen², David Banji 1,* \\ ${ }^{1}$ Pharmacy Practice Research Unit, Department of Clinical Pharmacy, College of Pharmacy, Jazan University, SAUDI ARABIA. \\ ${ }^{2}$ College of Pharmacy, Jazan University, Jazan, SAUDI ARABIA.
}

\begin{abstract}
Objectives: Pharmacy program offers many entrepreneurial opportunities in hospital, community and industrial sectors. Entrepreneurship is recognized, implemented and encouraged in many Universities around the world as a separate program to ease out the problems of unemployment. However, not all pharmacy students can afford to study dual programs to become an entrepreneur; hence, it would be worthwhile if it included in the PharmD curriculum. Methods: To assess the preconception of pharmacy students for the inclusion of entrepreneurial courses in the PharmD program, a descriptive, crosssectional survey method was adopted. One hundred and five senior PharmD students were selected to respond to the structured questionnaire, on the Likert scale, which contained six domains with fifty-six questions. Content validity of the questionnaire was performed, and the reliability of the questionnaire was assessed using Cronbach's Alpha. The survey was conducted from February to March 2019. Outcomes were computed into mean scores, and Spearman's Rho was computed using SPSS version 23. Results: The study revealed that students possessed adequate entrepreneurial knowledge, mindset, personality, and attitude; however, they lacked confidence and skills in venturing into the task after their graduation. The majority of the students strongly agreed to the concept of entrepreneurship and were interested in overcoming their weaknesses. Conclusion: It could be concluded that entrepreneurial activities must be strengthened among pharmacy students by designing and adopting a suitable curriculum to encourage self-employment.
\end{abstract}

Key words: PharmD, Entrepreneurship, Personality, Knowledge, Attitude,

Self-employment.

\section{INTRODUCTION}

Pharmacy profession is growing with the incorporation of new ideas, concepts and technology, to provide better pharmaceutical care to patients. Students of Pharmacy are taught and trained in Universities and colleges to handle patient needs and to provide them with effective pharmaceutical care, thereby to improve quality of life. Recently, however, fresh emerging graduates are confronting the scarcity of employment opportunities, as hospitals and community pharmacies are facing saturation. A finite number of posts sanctioned in health care centers makes employment opportunity for PharmD graduates limited. With this trend, new job opportunities need to be created, which is possible by encouraging entrepreneurial activities in the region or motivating existing entrepreneurs to widen their horizons.

All existing health care centers are flooded with patients in Saudi Arabia, indicating a massive gap between service providers and receivers. If pharmacists view themselves as entrepreneurs, future employment problem can be lessened, there could be better delivery of health care and importantly, better professional satisfaction. The Center for the Advancement of Pharmacy Education (CAPE) has also recommended the
Submission Date: 26-07-2019; Revision Date: 04-09-2019; Accepted Date: 12-11-2019

DOI: 10.5530/ijper.54.1.4 Correspondence: Dr. David Banji, Professor, Department of Clinical Pharmacy, Pharmacy Practice Research Unit, College of Pharmacy, Jazan University, KINGDOM OF SAUDI ARABIA.

Phone: +966-0557942809 E-mail: davidbanji@gmail. com

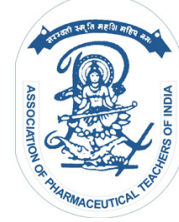

www.ijper.org 
Accreditation Council for Pharmacy Education (ACPE) to include entrepreneurship within domains to evaluate professional pharmacy programs. American Association of Colleges of Pharmacy (AACP) Academic Affairs Standing Committee too identified entrepreneurship as a vital realm where students can develop feasible and livable skills. ${ }^{1}$

An entrepreneur is the one who sets up, operates a business and assumes higher financial risks to achieve it. $^{2}$ However, the challenge before the educators are to foster entrepreneurial skills in pharmacists. In developing countries, the goal of education is to achieve the intended outcomes which are different from developed countries. ${ }^{3}$ The current educational program offered at Universities barely enables young people to acquire skills and competency needed for self-employment. ${ }^{4}$ The issue, therefore, is to make the emerging young pharmacists capable and confident enough to venture into entrepreneurial activities. Accordingly, Universities need to advocate entrepreneurial skill development programs encompassing business skills, personality dimensions, specific entrepreneurial traits, skills on the labor market, communication, teamwork, adaptability and emotional management for successful self-employment. ${ }^{5}$ In Saudi Arabia, pharmacy education has undergone metamorphosis and is almost on par with the standards of the western world.

Students in Saudi Arabia are pursuing the Doctoral program in Pharmacy to join a public sector organization; however, they have not focused on entrepreneurial activities so far. Also, there are no studies undertaken as on date to understand the preconception of pharmacy students towards entrepreneurial activities. Hence, the current study was aimed to understand the preconception of PharmD students towards self-employment by assessing their personality, mindset, knowledge, skills and attitude; so that, suitable education programs can be designed to shape individual skills to facilitate entrepreneurship.

\section{MATERIALS AND METHODS}

\section{The research design}

This study is a descriptive, cross-sectional survey method in the form of a structured questionnaire, consisting of Likert five-grade scale questions. The questionnaire was prepared based on literature survey. ${ }^{6-9}$ Male pharmacy PharmD interns and final year students were invited to participate (respondents). The study included these students as they would graduate within a short period and would need to make career plans.
Also, the senior pharmacy students were more likely to incline entrepreneurship because of their increased exposure to community pharmacy, clinical clerkship and pharmacy management courses. The questionnaire prepared to assess preconception comprised of five measurable domains such as personality, knowledge, mindset, skillset and attitude of students towards entrepreneurship. Section A of the questionnaire focused on demographic issues; section $\mathrm{B}$ had nine questions to assess personality; section $\mathrm{C}$ assessed the knowledge (15 questions) of the respondents; section $\mathrm{D}$ had questions to assess the skill set ( 9 questions); section $\mathrm{E}$ had four questions to understand their mindset; and, section $\mathrm{F}$ assessed attitude towards entrepreneurship with 7 questions. Students responses were recorded with a 5-point Likert scale rating; $1=$ Strongly Disagree; 2. Disagree; 3=I don't know; 4=Agree; 5 Strongly Agree. The Likert scale was selected to enable interns to accurately assess their level of agreement in a familiar format without any confusion. The questions were audited by subject experts and individuals with entrepreneurial experience to ensure that questions were accurate and understandable. A Pilot study was conducted to assess feasibility of answering the questions. As the questions were easily understandable, no ambiguity and no conflict of opinions among the participants of the pilot study, we proceeded with the questionnaire and included their responses in the final study.

\section{Data collection method}

The survey questionnaire was distributed among one hundred and ten students of PharmD program. The eligible students were included in this study if they were in their final year and interns of the PharmD program at the College of Pharmacy. The questionnaire was anonymous and distributed to all the students during their regular educational activities from $3^{\text {rd }}$ February 2019 to $7^{\text {th }}$ February 2019 and 105 students responded $(n-105)$. As the survey was recorded during the regular academic activities, enough measures were taken to ensure that students did not feel any pressure to participate and responses were made anonymous to avoid any performance bias. An encouraging environment was established so that they could respond freely and to avoid overstating their knowledge, skills and attitude to impress the supervisor. The two technical characteristics, validity and reliability, of the questionnaire, have been studied.

\section{A: Validity}

It is the measure of the scale and content of the questions designed in the research tool (questionnaire) 
exactly the variables and the subject under study. Content validity was used in the study, which was evaluated by the qualified individuals and necessary corrections were made for each of the questions.

\section{B. Reliability}

In the current study, Cronbach's Alpha was determined to find out the internal consistency coefficient of the item response to the questionnaire, Table 1. For questions about knowledge related to entrepreneurship the value for Cronbach's Alpha was 0.88 ; personality 0.863 ; mindset 0.91 ; skillset 0.90 ; and attitude 0.69 .

\section{Ethical issues}

Permission was first sought and granted by the college authorities before the questionnaire was distributed and administered. Respondents' consent was obtained after the purpose of the study was explained and they were informed that their participation was voluntary. The confidentiality and anonymity of the respondents were ensured.

\section{Data Analysis}

The data obtained were entered into Excel and analyzed using SPSS (IBM Corporation, NY, USA) software, version 23, for descriptive and inferential analysis. Frequency and percentage were reported. Cronbach's Alpha was assessed to determine the internal consistency of items under each domain.

Also, items under the domains of knowledge, attitude, skill set, personality and mindset were combined separately to obtain a mean score. Shapiro-Wilk test showed $p<0.05$ indicating deviation from normality; besides, the data also exhibited skewness; hence, correlation using Spearman's Rho was computed. An association between the demographic variables with mean scores derived for each domain was determined. Also, an association between mean knowledge score with mean attitude score, mean personality score, mean skillset score and mean motivation score was also established. $P<0.05$ was considered statistically significant.

\section{RESULTS}

Of the 110 male students, 105 responded to the questionnaire giving a response rate of $95.45 \%$. Majority of the students were between the age of 21-30 years $(96.2 \%)$. A more substantial part of them had an annual household income of 10,000 to 25,000 SAR (64.8\%) per annum. Final year PharmD students (43.8\%) and interns $(56.2 \%)$ participated in the study. Similarly, 93.3\% students were from Jazan province and very few from the other parts of $\mathrm{KSA} ; 81.0 \%$ were from a tiny town in
Jazan province, $7.6 \%$ students from a rural background and $11.4 \%$ were from urban regions of KSA, Table 2.

\section{Personality}

To assess the personality of the students about entrepreneurial activities, questions were asked regarding their interest in facing risk related to commitment and accountability for the task accepted. The response for all these eight questions was either agree or strongly agree except for a question on doing new things in life, the average answer was, I don't know (56.20\%). Students strongly agreed that they would be happy if their dreams turned into reality $(65.70 \%)$; and agreed that they would be emotionally charged to make a change $(65.70 \%)$. Similarly, they strongly agreed $(53.3 \%)$ in identifying the opportunities that challenge the status quo. Majority of the students agreed that they are reliable, accountable and others can count on them (Table 3).

\section{Knowledge}

To assess their knowledge on entrepreneurship, fifteen questions were asked and their responses are shown in Table 4. A positive response, strongly agrees, to almost all the questions related to entrepreneurship except for two questions viz., 1. They had not studied any subject related to entrepreneurship in their PharmD program $(44 \%)$ and 2 . the subject that they studied had not provided them with enough knowledge on entrepreneurship $(47.6 \%)$. More than fifty percent of the students have strongly agreed that they would like to work for themselves after PharmD degree (54.3\%); working for themselves would bring them success and satisfaction in life $(59.0 \%)$ and work for self is enjoying and rewarding (50.5). They too strongly agreed that they were aware of the essential qualities to be a successful entrepreneur; such as, entrepreneurs are risk-takers $(49.5 \%)$; great leadership qualities (57.1\%); excellent communication skills $(60.0 \%)$; have clear vision and mission of their responsibilities ( $49.5 \%$ ); and capable of creating a healthy and encouraging working environment (48.6\%). Overall, it indicates that students have knowledge about the entrepreneur, entrepreneurship and entrepreneurial activities, but they never had a course in their PharmD program to enrich or nourish it further.

\section{Skillset}

The responses of students on skillset are shown in Table 5. Negative responses were documented for all questions asked except two. Students agreed that they have a conviction of becoming an entrepreneur in the future $(63 \%)$ and they possess excellent organizing skills $(64.8 \%)$. It is observed that they were not confident in answering two questions -1. about their effectiveness 


\begin{tabular}{|c|c|c|}
\hline \multicolumn{2}{|c|}{ Table 1: Cronbach's Alpha coefficient. } \\
\hline Variable & items & Cronbach's Alpha score \\
\hline Personality & 8 & 0.86 \\
\hline Knowledge & 15 & 0.88 \\
\hline Mindset & 4 & 0.91 \\
\hline Skill set & 16 & 0.90 \\
\hline Attitude & 4 & 0.69 \\
\hline
\end{tabular}

\begin{tabular}{|c|c|}
\hline Demographic variables & $\mathrm{N}(\%)$ \\
\hline \multicolumn{2}{|l|}{ Age } \\
\hline $15-20$ years & $3(2.9)$ \\
\hline $21-30$ years & 101(96.2) \\
\hline$>30$ years & $9(1.0)$ \\
\hline \multicolumn{2}{|l|}{ Education } \\
\hline Final year & $59(56.2)$ \\
\hline Interns & $46(43.8)$ \\
\hline \multicolumn{2}{|l|}{ Household Income } \\
\hline$<10000$ SAR per month & $36(34.8)$ \\
\hline $10001-25,000$ SAR per month & $68(64.8)$ \\
\hline$>25,001$ SAR per month & $1(1.0)$ \\
\hline \multicolumn{2}{|l|}{ Region } \\
\hline Jazan & $98(93.3)$ \\
\hline South Saudi Arabia & $4(3.8)$ \\
\hline North Saudi Arabia & $3(2.9)$ \\
\hline \multicolumn{2}{|l|}{ Residence Type } \\
\hline Rural & $8(7.6)$ \\
\hline Small City & $85(81.0)$ \\
\hline Urban & $12(11.4)$ \\
\hline
\end{tabular}

$\mathrm{N}=$ Number of participants

in communication skills in convincing business plans $(52.4 \%)$ and 2. about carrying out business SWOT (strengths, weaknesses, opportunities and threats) analysis on their own (55.2\%), which evidenced as "I don't know". Out of twelve questions responded negatively, nine questions were strongly disagreed upon- developing a business report (40\%); on designing product / service items of new business (41.9\%); understanding consumers attitude and behavior to run the business (49.5\%); conducting a market survey $(39.0 \%)$; technique of selling $(41.0 \%)$; determining pricing strategies of the products $(43.8 \%)$; understanding the financial requirements to start and run business (53.3\%); meeting all the official and regulatory requirements of setting up of the business (39.0\%); getting the writeups done well to secure financial assistance from the creditors (45.7\%); and they disagreed upon three questions, i.e., on understanding the channel of marketing (57.1\%); preparation of budget (59.05); and on interpreting the financial statements $(44.8 \%)$. Overall, it is observed that majority of the students have no required skills for entrepreneurial activities even though they have awareness about entrepreneurship.

\section{Mindset}

Student's response to mindset questions is presented in Figure 1. Strong positive responses were observed for all the questions asked. They have agreed that business is risk-taking $(70.5 \%)$, requires ethics apart from making a profit $(70.5 \%)$, requires hard work $(55.2 \%)$ and it involves a lot of hardship (61.5\%).

\section{Attitude}

The outcomes for attitude response are shown in Figure 2. Students agreed that venturing into a different track $(60 \%)$ and exploring the unexplored field $(57.1 \%)$ is difficult for them and had confusion on trying something new $(53.3 \%)$. However, they agreed that they have the creativity and can come up with new ideas to overcome their shortcomings. Students have shown a strong attitude for entrepreneurial activities.

The scores for each item under each of the domains were averaged to obtain the mean scores. In order to assess the correlation between the demographic variables with the mean scores, Spearman's 'Rho' was computed, Table 6 . A weak positive correlation was observed between age and mean skill score, $r=-0.244, p=0.012$. However, a correlation was not observed between mean scores attained in knowledge, attitude, personality and mindset domains with age.

Household income was moderately correlated with mean knowledge score $(\mathrm{r}=0.54, p<0.001)$, mean personality score $(\mathrm{r}=0.440, p<0.001)$ and mean mindset score $(\mathrm{r}=0.506, p<0.001)$ and showed a weak negative correlation with mean skill score $\mathrm{r}=-0.306, p=0.002$.

The region from where the students belonged exhibited a weak positive correlation with mean skill score $\mathrm{r}=0.261, p=0.007$. However, education and residence type were not significantly correlated with any of these scores.

A significant positive correlation was observed between mean knowledge score with mean mindset score $(\mathrm{r}=0.823, p<0.001)$ and mean personality score $(\mathrm{r}=0.876, p<0.001)$; whereas, mean knowledge score was negatively correlated to skillset score $(\mathrm{r}=-0.537$, $p<0.001$ ), Table 7. Mean knowledge score was not correlated with mean attitude score. 


\begin{tabular}{|c|c|c|c|c|c|c|c|c|}
\hline \multirow{2}{*}{ Personality questions } & \multicolumn{5}{|c|}{ Participants' response, N (\%) } & \multirow[b]{2}{*}{ Mean } & \multirow[b]{2}{*}{$\begin{array}{l}\text { Std. } \\
\text { Div. }\end{array}$} & \multirow[b]{2}{*}{$\mathbf{N}$} \\
\hline & $\begin{array}{l}\text { Strongly } \\
\text { Disagree }\end{array}$ & Disagree & I don't know & Agree & $\begin{array}{l}\text { Strongly } \\
\text { Agree }\end{array}$ & & & \\
\hline $\begin{array}{l}\text { I challenge and overcome hurdles } \\
\text { to my ideas }\end{array}$ & $2(1.9)$ & 18(17.1) & $9(8.6)$ & $66(62.9)$ & $10(9.5)$ & 3.61 & .946 & 105 \\
\hline $\begin{array}{l}\text { I like to witness my ideas turn into } \\
\text { reality }\end{array}$ & $6(5.7)$ & $5(4.8)$ & $16(15.2)$ & $9(8.6)$ & $69(65.7)$ & 4.24 & 1.213 & 105 \\
\hline I identify opportunities easily & $0(0.00)$ & $9(8.6)$ & $16(15.2)$ & $24(22.9)$ & $56(53.3)$ & 4.21 & .997 & 105 \\
\hline I challenge the status quo & $0(0.00)$ & $15(14.3)$ & 14(13.3) & $63(60.0)$ & $13(12.4)$ & 3.70 & .865 & 105 \\
\hline $\begin{array}{c}\text { I am confused when I want to do } \\
\text { new things in my life }\end{array}$ & $8(7.6)$ & $22(21.0)$ & $59(56.2)$ & $10(9.5)$ & $6(5.7)$ & 2.85 & .907 & 105 \\
\hline $\begin{array}{l}\text { I runout of my ideas when I want to } \\
\text { do new things }\end{array}$ & $10(9.5)$ & $20(19.0)$ & $8(7.6)$ & 18(17.1) & $49(46.7)$ & 3.72 & 1.451 & 105 \\
\hline $\begin{array}{c}\text { I am eager and emotionally } \\
\text { charged to make a change in my } \\
\text { life }\end{array}$ & $4(3.8)$ & $12(11.4)$ & $16(15.2)$ & $69(65.7)$ & $4(3.8)$ & 3.54 & .888 & 105 \\
\hline $\begin{array}{l}\text { I am reliable and accountable. } \\
\text { Others can count on me. }\end{array}$ & $5(4.8)$ & $12(11.4)$ & $17(16.2)$ & $21(20.0)$ & $50(47.6)$ & 3.94 & 1.239 & 105 \\
\hline
\end{tabular}

$\mathrm{N}=$ Number of participants.

\section{DISCUSSION}

The current study was carried out to understand the preconception of pharmacy students about entrepreneurial activities and introducing it as a course in the PharmD program. Most of the universities in the Kingdom of Saudi Arabia, including Jazan University, have not yet introduced entrepreneurship as a subject in their degree program. The traditional and conventional approaches in teaching pharmacy program with core professional subjects are incorrect and inappropriate and have been a liability for entrepreneurship. However, the "value-added" in the program, such as entrepreneurship, would be the best choice. Providing the necessary training in entrepreneurial skills to pharmacy students will assist them in coming up with their own businesses and to consider self-employment as a career option on completion of their PharmD program. Entrepreneurship is a set of capacitating skills and knowledge collaborated with a confident mindset. Hence, this study is appropriate to assess the students' preconception about entrepreneurial activities, their knowledge, personality, skillset, mindset and attitude, before introducing an additional course or a program on entrepreneurship. Majority of the participants strongly agreed to the concept of becoming an entrepreneur in our study and they opined that entrepreneurship education and activities should not be restricted to business education students but must be extended to pharmacists also, as the profession offers many business opportunities. Hence, this reflects a gap in the current education system to develop entrepreneurial intentions and promote entrepreneurship among PharmD graduates.

Culture of entrepreneurship is the reflection of personality characteristics. Therefore, the personality of the individual is one of the crucial factors in assessing entrepreneurial preconception, ${ }^{10}$ providing valuable insight into the mind of the students. ${ }^{11}$ A positive mind supports an entrepreneurial initiative and planned behavior is essential for the success of entrepreneurship. Positive personality and attitude are required in an individual to generate an action plan for enterprise formation. ${ }^{12}$ Entrepreneurial proactivity is the potential of an individual to be action-oriented and complete a task. Proactivity indicates a high level of energy, goal orientation and competitive nature of an individual. Proactive individuals are confident and willing to take risks, persist in the face of adversity and are not deterred by uncertainty or fear of failure. The study revealed that final year students and interns of the PharmD program were equally proactive towards entrepreneurship. Their positive response towards accepting challenges and overcoming hurdles to realize their ideas, looking forward to witnessing their ideas turn into reality, challenging the status quo to seek better entrepreneurial opportunities and attaching emotion and eagerness in making a change in their life are the indicators for the proactiveness and energetic personality of the responders. Personality 


\begin{tabular}{|c|c|c|c|c|c|c|c|c|}
\hline \multirow[b]{2}{*}{ Knowledge questions } & \multicolumn{5}{|c|}{ Participants' response, N (\%) } & \multirow[b]{2}{*}{ Mean } & \multirow[b]{2}{*}{$\begin{array}{l}\text { Std. } \\
\text { Div. }\end{array}$} & \multirow[b]{2}{*}{$\mathbf{N}$} \\
\hline & $\begin{array}{l}\text { Strongly } \\
\text { Disagree }\end{array}$ & Disagree & $\begin{array}{l}\text { I don't } \\
\text { know }\end{array}$ & Agree & $\begin{array}{l}\text { Strongly } \\
\text { Agree }\end{array}$ & & & \\
\hline I am aware who is an entrepreneur & $4(3.8)$ & $8(7.6)$ & $20(19.0)$ & $27(25.7)$ & $46(43.8)$ & 3.98 & 1.135 & 105 \\
\hline $\begin{array}{l}\text { In understand that entrepreneurs are the } \\
\text { greatest achievers in life }\end{array}$ & $1(1.0)$ & $13(12.4)$ & $21(20.0)$ & $24(22.9)$ & $46(43.8)$ & 3.96 & 1.109 & 105 \\
\hline $\begin{array}{l}\text { I know that they have a great position in } \\
\text { the society }\end{array}$ & $11(10.5)$ & $0(0.0)$ & 19(18.1) & $23(21.9)$ & $52(49.5)$ & 4.10 & 1.046 & 105 \\
\hline $\begin{array}{c}\text { After my PharmD, I would like to work for } \\
\text { myself }\end{array}$ & $8(7.6)$ & 10(9.5) & $10(9.5)$ & $20(19.0)$ & $57(54.3)$ & 4.03 & 1.312 & 105 \\
\hline $\begin{array}{l}\text { I know that if I work for myself, I can lead } \\
\text { a great satisfying and successful life }\end{array}$ & $4(3.8)$ & $5(4.8)$ & $15(14.3)$ & 19(18.1) & $62(59.0)$ & 4.24 & 1.105 & 105 \\
\hline $\begin{array}{l}\text { I would like to work for myself rather than } \\
\text { working for others }\end{array}$ & $7(6.7)$ & $13(12.4)$ & 18(17.1) & $11(10.5)$ & $56(53.3)$ & 3.91 & 1.345 & 105 \\
\hline $\begin{array}{l}\text { Working for self is enjoying and } \\
\text { rewarding. }\end{array}$ & $6(5.7)$ & $7(6.7)$ & $12(11.4)$ & $27(25.7)$ & $53(50.5)$ & 4.09 & 1.186 & 105 \\
\hline $\begin{array}{c}\text { I know that the entrepreneurs are the risk } \\
\text { takers }\end{array}$ & $5(4.8)$ & $4(3.8)$ & 18(17.1) & $26(24.8)$ & $52(49.5)$ & 4.10 & 1.117 & 105 \\
\hline $\begin{array}{l}\text { I know that the entrepreneurs have great } \\
\text { leadership qualities }\end{array}$ & $11(10.5)$ & $0(0.0)$ & $16(15.2)$ & $18(17.1)$ & $60(57.1)$ & 4.21 & 1.053 & 105 \\
\hline $\begin{array}{l}\text { I am aware that entrepreneurs have good } \\
\text { communication skills }\end{array}$ & $14(13.3)$ & $0(0.0)$ & $16(7.6)$ & $20(19.0)$ & $63(60.0)$ & 4.26 & 1.074 & 105 \\
\hline $\begin{array}{l}\text { I am aware that entrepreneurs have } \\
\text { a clear vision and mission of their } \\
\text { responsibilities }\end{array}$ & $1(1.0)$ & $13(12.4)$ & $22(21.0)$ & $17(16.2)$ & $52(49.5)$ & 4.01 & 1.139 & 105 \\
\hline $\begin{array}{l}\text { I am aware know that entrepreneurs } \\
\text { are efficient in creating healthy and } \\
\text { encouraging working environment }\end{array}$ & $3(2.9)$ & $13(12.4)$ & 19(18.1) & $19(18.1)$ & $51(48.6)$ & 3.97 & 1.197 & 105 \\
\hline $\begin{array}{l}\text { I have studied a subject related to } \\
\text { entrepreneurship in my current program }\end{array}$ & $46(43.8)$ & $12(11.4)$ & $27(25.7)$ & $14(13.3)$ & $6(5.7)$ & 2.26 & 1.301 & 105 \\
\hline $\begin{array}{l}\text { The subject that I studied has provided } \\
\text { me the enough knowledge about } \\
\text { entrepreneurship }\end{array}$ & $50(47.6)$ & $13(12.4)$ & $20(19.0)$ & 18(17.1) & $4(3.8)$ & 2.17 & 1.297 & 105 \\
\hline $\begin{array}{l}\text { I think, I need a course on } \\
\text { entrepreneurship along with current } \\
\text { program }\end{array}$ & $5(4.8)$ & $6(5.4)$ & $22(21.0)$ & $19(18.1)$ & $53(50.5)$ & 4.04 & 1.176 & 105 \\
\hline
\end{tabular}

$\mathrm{N}=$ Number of participants

traits are suggested to have a more decisive influence on the decisions to become an entrepreneur (11). ${ }^{13}$

The study revealed that students are adequately informed and knowledgeable about entrepreneurial activities and have the mindset to go for new business ventures if appropriate encouragement is provided. They are willing to take a risk and work hard to have their own business. Students often enter professional courses intending to gain government employment; despite this, they have shown a keen interest in entrepreneurship. It is evident from this study that education and academic training are essential for entrepreneurship and the encouraging point is that students are well versed with entrepreneurial activities. Our study has exhibited a strong correlation between knowledge and personality; knowledge and mindset; however, a negative correlation between knowledge and skillset; reflects that students are well informed, are willing and prepared to undertake risk and responsibilities of entrepreneurial activities but lack confidence. Low confidence stems from a lack of entrepreneurial skills. Developing these skills among youth is the need of the hour and is crucial to becoming an entrepreneur.

Demographical variable such as age, education (a final year or interns of Pharm.D program) and residence type have no impact on any of the variables studied; whereas, household income positively influences knowledge gained, mindset and personality and no impact on skillset. According to Donna and Holtz, household income provides essential support for entrepreneurial aspira- 


\begin{tabular}{|c|c|c|c|c|c|c|c|c|}
\hline \multirow[b]{2}{*}{ Skills questions } & \multicolumn{5}{|c|}{ Participants' response, N (\%) } & \multirow[b]{2}{*}{ Mean } & \multirow[b]{2}{*}{$\begin{array}{l}\text { Std. } \\
\text { Div. }\end{array}$} & \multirow[b]{2}{*}{$\mathbf{N}$} \\
\hline & $\begin{array}{l}\text { Strongly } \\
\text { Disagree }\end{array}$ & Disagree & $\begin{array}{l}\text { I don't } \\
\text { know }\end{array}$ & Agree & $\begin{array}{l}\text { Strongly } \\
\text { Agree }\end{array}$ & & & \\
\hline $\begin{array}{l}\text { On conviction of becoming an entrepreneur in } \\
\text { future }\end{array}$ & $5(4.8)$ & $4(3.8)$ & 14(13.3) & $63(60.0)$ & 19(18.1) & 3.83 & .935 & 105 \\
\hline On developing a business concept & $42(40.0)$ & $10(9.5)$ & $20(19.0)$ & $28(26.7)$ & $5(4.8)$ & 2.47 & 1.373 & 105 \\
\hline $\begin{array}{l}\text { On designing product / service items of new } \\
\text { business }\end{array}$ & $44(41.9)$ & $11(10.5)$ & 14(13.3) & $29(27.6)$ & $7(6.7)$ & 2.47 & 1.435 & 105 \\
\hline $\begin{array}{l}\text { On understanding consumers attitude and } \\
\text { behaviors to run the business }\end{array}$ & $52(49.5)$ & $0(0.0)$ & 19(18.1) & $26(24.8)$ & $8(7.6)$ & 2.90 & 1.024 & 105 \\
\hline $\begin{array}{l}\text { On convincing about the business plan / ideas } \\
\text { to others }\end{array}$ & $1(1.0)$ & $9(8.6)$ & $55(52.4)$ & $32(30.5)$ & $8(7.6)$ & 3.35 & 0.784 & 105 \\
\hline On conducting a market survey & $41(39.0)$ & 23(21.9) & 13(12.4) & $22(21.0)$ & $6(5.7)$ & 2.32 & 1.334 & 105 \\
\hline On techniques of selling & $43(41.0)$ & 20(19.0) & $18(17.1)$ & $19(18.1)$ & $5(4.8)$ & 2.27 & 1.295 & 105 \\
\hline $\begin{array}{l}\text { On determining pricing strategies of the } \\
\text { products }\end{array}$ & $46(43.8)$ & 18(17.1) & $13(12.4)$ & 18(17.1) & $10(9.5)$ & 2.31 & 1.423 & 105 \\
\hline On understanding the channels of marketing & $4(3.8)$ & $60(57.1)$ & $22(21.0)$ & 18(17.1) & $1(1.0)$ & 2.54 & .855 & 105 \\
\hline On preparation of budget & $3(2.9)$ & $62(59.0)$ & 15(14.3) & 14(13.3) & $11(10.5)$ & 2.70 & 1.084 & 105 \\
\hline $\begin{array}{l}\text { On understanding the financial requirements to } \\
\text { start and run business }\end{array}$ & $56(53.3)$ & 14(13.3) & $20(19.0)$ & $13(12.4)$ & $2(1.9)$ & 3.29 & 2.973 & 105 \\
\hline $\begin{array}{l}\text { On meeting all the official and regulatory } \\
\text { requirements of setting up of the business }\end{array}$ & $41(39.0)$ & $17(16.2)$ & 18(17.1) & 11(10.5) & 18(17.1) & 2.50 & 1.514 & 105 \\
\hline $\begin{array}{l}\text { On getting all the writeups done well to secure } \\
\text { financial assistance from the creditors }\end{array}$ & $48(45.7)$ & $13(12.4)$ & $31(29.5)$ & $11(10.5)$ & $2(1.9)$ & 2.10 & 1.160 & 105 \\
\hline On interpreting the financial statements & $7(6.7)$ & $47(44.8)$ & $21(20.0)$ & $27(25.7)$ & $3(2.9)$ & 2.73 & 1.012 & 105 \\
\hline $\begin{array}{l}\text { On performing SWOT analysis of the new } \\
\text { products with that exists in the market }\end{array}$ & $5(4.8)$ & $12(11.4)$ & $58(55.2)$ & $24(22.9)$ & $6(5.7)$ & 3.13 & .867 & 105 \\
\hline On Organizing Skills & $2(1.9)$ & $10(9.5)$ & 19(18.1) & $68(64.8)$ & $6(5.7)$ & 3.63 & .812 & 105 \\
\hline
\end{tabular}

$\mathrm{N}=$ Number of participants

\begin{tabular}{|c|c|c|c|c|c|}
\hline \multirow{2}{*}{$\begin{array}{c}\text { Demographic } \\
\text { Variable }\end{array}$} & \multicolumn{5}{|c|}{ Correlation coefficient ( $r$ ) } \\
\hline & KTM (P-value*) & STM(P-value*) & ATM(P-value*) & MTM(P-value*) & PTM(P-value*) \\
\hline Age & $0.084(0.396)$ & $0.244(0.012)$ & $0.076(0.439)$ & $0.091(0.353)$ & $0.029(0.769)$ \\
\hline Education & $0.117(0.236)$ & $0.016(0.871)$ & $0.066(0.502)$ & $0.035(0.726)$ & $0.118(0.232)$ \\
\hline Household Income & $0.54\left(0.001^{*}\right)$ & $-0.306\left(0.002^{*}\right)$ & $0.133(0.177)$ & $0.506\left(0.001^{*}\right)$ & $0.440\left(0.001^{*}\right)$ \\
\hline Region & $0.059(0.546)$ & $0.261\left(0.007^{*}\right)$ & $0.033(0.738)$ & $-0.111(0.261)$ & $-0.173(0.078)$ \\
\hline Residence type & $0.028(0.777)$ & $0.134(0.172)$ & $-0.047(0.635)$ & $0.063(0.526)$ & $-0.175(0.074)$ \\
\hline
\end{tabular}

*Correlation significant at P<0.01 level; KTM= Mean Knowledge Score; STM = Mean Skill Score; ATM=Mean Attitude Score; MTM=Mean Mindset Score; PTM=Mean Personality Score.

\begin{tabular}{|c|c|c|}
\hline \multicolumn{2}{|c|}{ Table 7: Correlation between knowledge, attitude, personality, skills and Mindset score. } & $\boldsymbol{P}_{\text {-value }}{ }^{*}$ \\
\hline Variable & Correlation coefficient & 0.470 \\
\hline Knowledge-Attitude & 0.071 & 0.001 \\
\hline Knowledge-Personality & 0.876 & 0.001 \\
\hline Knowledge-Mindset & 0.823 & 0.001 \\
\hline Knowledge-skillset & -0.537 & \\
\hline
\end{tabular}

\footnotetext{
*Correlation significant at $P<0.01$ levels (2 tailed).
} 


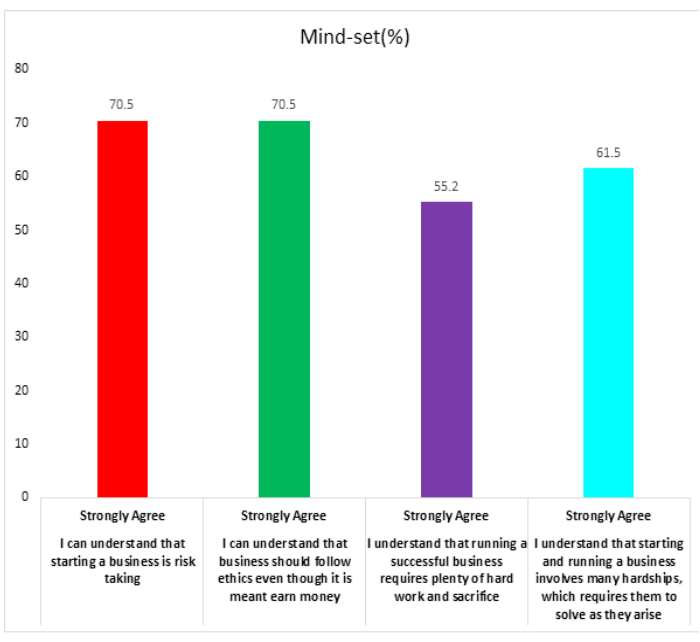

Figure 1: Mindset of the respondents towards entrepreneurship.

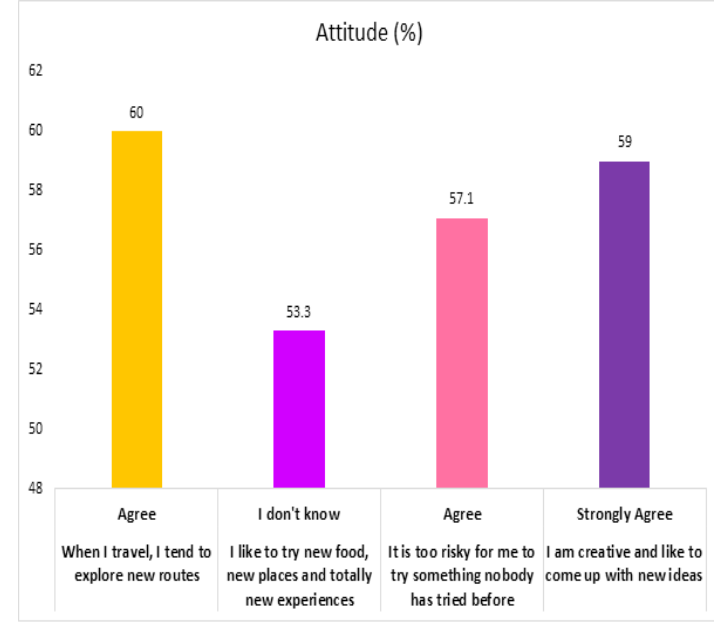

Figure 2: Attitude of the respondents towards entrepreneurship.

tion, where students from affluent and high-income households can generate financial resources to propel entrepreneurial firm growth ${ }^{14}$ apart from having social connections to derive better growth opportunities. The region, urban or rural, has exhibited a positive relationship on skillset, but not on other variables, indicating that additional training and exposure would be required to develop them into entrepreneurs.

Therefore, this study reiterates that PharmD students are positively oriented towards entrepreneurship and are keen to have entrepreneurial education as one of the courses in their PharmD program, to develop themselves as future entrepreneurs. The Institutions and the University should come forward to arrange formal education to equip these competitive young people by imparting adequate skills and tools to promote confidence, to transform their ideas into working business ventures and to enable them to identify business oppor- tunities. There is a need for professionals turning into entrepreneurs who can orient towards critical thinking, outcomes-based managing skills, risk-taking with creativity, looking continuously for improvement and are resilient. Society requires and needs more and more such human resources; highly trained, skilled and qualified to develop innovative ideas that will be transformed into real, social and sustainable projects.

\section{Limitation}

This study was limited to the opinion of the current senior PharmD students of one University. Hence, the outcomes of this study can give us only an indication of the respondents' perceptions for the inclusion of entrepreneurial education in PharmD curriculum of this University which could be extended to views of the students of other Universities of the Kingdom of Saudi Arabia as the educational concept, policies, facilities, skill orientation and program imparting techniques remains same. However, a separate study of a larger magnitude, involving the students of all the Universities of the Kingdom, would be beneficial to confirm our findings.

\section{CONCLUSION}

The study tested the preconception of pharmacy students towards the introduction of an entrepreneurial course in the PharmD curriculum. Pharmacy students expressed concerns about their career; however, they also believed that entrepreneurship is the way out for their apprehension. Even though they possess adequate knowledge, mindset and personality towards entrepreneurship, they lacked the vital skills and confidence needed to be an entrepreneur. Besides, they exhibited a fear of entrepreneurial activities. Hence to develop their skills, they envisioned the inclusion of an entrepreneurial course in the PharmD curriculum, which would benefit them in improving their competence and overcoming career-associated distress.

\section{ACKNOWLEDGEMENT}

The authors would like to express thanks to Prof. Otilia J F Banji for reviewing this manuscript; Dr. Saad Saeed Alqahtani, HOD, Department of Clinical Pharmacy, Jazan University, Jazan, for his constant support and encouragement; and Mr. Nabeel Kashal for helping in conducting the survey.

\section{CONFLICT OF INTEREST}

The authors declare no conflict of interest. 


\section{ABBREVIATIONS}

CAPE: Center for the Advancement of Pharmacy Education; ACPE: Accreditation Council for Pharmacy Education; AACP: American Association of Colleges of Pharmacy; KAEC: King Abdullah Economic City.

\section{REFERENCES}

1. Mattingly $T J$, Mullins $C D$, Melendez DR, Boyden $K$, Eddington ND. Entrepreneurship in Pharmacy Practice and Education: A Systematic Review. Am J Pharm Educ. 2019;83(3):7233.

2. Premand P, Brodmann S, Almeida R, Grun R, Barouni M. Entrepreneurship Education and Entry into Self-Employment Among University Graduates. World Dev. 2016;77:311-27.

3. Aljadhey H, Asiri Y, Albogami Y, Spratto G, Alshehri M. Pharmacy education in Saudi Arabia: A vision of the future. Saudi Pharm J. 2017;25(1):88-92.

4. Behzadfar M, Shahmoradi M. The Relationship between Social Capital and the Level of Entrepreneurial Spirituality in the Students of Payame University in Hamadan. Int J Educ Res and Tech. 2018;9(2):40-6.

5. Sam AT, Parasuraman S. The Nine-Star Pharmacist: An Overview. J of Young Pharmacist. 2015;7(4):281-4

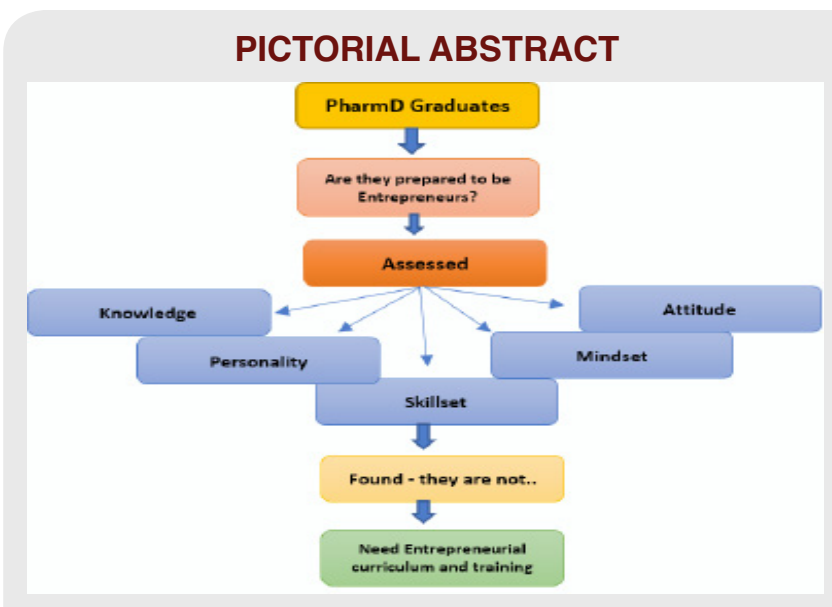

\section{About Authors}

Dr. Ahmed A. Albarraq, Associate Professor and ViceDean, Post-graduate Studies and Research, Pharmacy Practice Research Unit, Department of Clinical Pharmacy, College of Pharmacy, Jazan University, Jazan, Saudi Arabia.

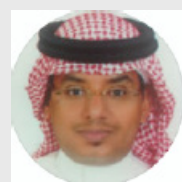

Hafiz A. Makeen, Asst. Professor and Dean, College of Pharmacy, Jazan University, Jazan, Saudi Arabia.

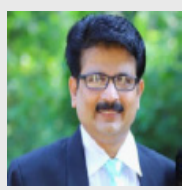

Dr. David Banji, Professor, Department of Clinical Pharmacy, and Chairman Pharmacy Practice Research Unit, College of Pharmacy, Jazan University, Jazan, Saudi Arabia.
6. Bin SG, Rezk NL, Laika L, Ali A, El-Metwally A. Pharmacist, the pharmaceutical industry and pharmacy education in Saudi Arabia: A questionnaire-based study. Saudi Pharm J. 2015;23(5):573-80.

7. Ramia E, Salameh P, Btaiche IF, Saad AH. Mapping and assessment of personal and professional development skills in a pharmacy curriculum. BMC Med Educ. 2016;16(1):19.

8. Odora RJ, Naong MN. Distigmatisation of Apprenticeship - A Vehicle for Entrepreneurship Promotion and Job Creation among Further Education and Training College Students. J Asian Afr Stud. 2014;49(4):457-72.

9. Laverty G, Hanna LA, Haughey S, Hughes C. Developing entrepreneurial skills in pharmacy students. Am J Pharm Educ. 2015;25;79(7):106.

10. Brandst"atter H. Personality Aspects of Entrepreneurship: A Look at Five Meta-Analyses. Personality and Individual Differences. 2011;51(3):222-30.

11. Ana IV, Nelu F. Impact of Personality Traits and Entrepreneurship Education on Entrepreneurial Intentions of Business and Engineering Students. Sustainability. 2019;11(4):1192.

12. Wang JH, Chang CC, Yao SN, Liang C. The contribution of self-efficacy to the relationship between personality traits and entrepreneurial intention. High Educ. 2015;72(2):209-24.

13. Develi EI, Sahin BE, Sevimli Y. Entrepreneurship and importance of personality on entrepreneurship: A research on trainees of entrepreneurship education program. Int J of Business and Management Studies. 2011;3(1):115-24.

14. Dunn T, Holtz-Eakin D. Financial capital, human capital and the transition to self-employment: Evidence From intergenerational links. Journal of Labor Economics. 2000;18(2):282-305.

\section{SUMMARY}

PharmD program offers many entrepreneurial opportunities for pharmacy students; yet, students fail to identify the chances and search for jobs soon after their graduation. In order to undertake entrepreneurial tasks, students need to receive training during their graduation; however, this seldom happens, resulting in a lack of entrepreneurial skills. The Government and the Universities emphasize and support developmental entrepreneurship activities among the students; hence, it would be beneficial if it is included in the PharmD curriculum to promote self-employment. Therefore, this study assessed students' perception and conception of including entrepreneurship in the PharmD curriculum. The study revealed that students possessed adequate knowledge, mindset, personality and attitude; however, they lacked confidence and skills in carrying out entrepreneurial activities after their graduation. Majority of the students strongly agreed to the concept of inclusion of entrepreneurship in the PharmD curriculum to overcome their weaknesses and perceived it as an encouragement towards self.

Cite this article: Albarraq AA, Makeen HA, Banji D. Preconception of Pharmacy Students for the Inclusion of Entrepreneurship Curriculum in the PharmD Program. Indian $\mathrm{J}$ of Pharmaceutical Education and Research. 2020;54(1):22-30. 